\title{
Nitrooxymethyl-Substituted Analogues of Celecoxib: Synthesis and Pharmacological Characterization
}

by Donatella Boschi, Loretta Lazzarato, Barbara Rolando, Andrea Filieri, Clara Cena, Antonella Di Stilo, Roberta Fruttero, and Alberto Gasco*

Dipartimento di Scienza e Tecnologia del Farmaco, Università degli Studi di Torino, Via Pietro Giuria 9, I-10125 Torino (phone: +390116707670; fax: +390116707286; e-mail: alberto.gasco@unito.it)

\footnotetext{
Nitrooxymethyl-substituted analogues of celecoxib were synthesized and tested for their cyclooxygenase (COX)-inhibiting, vasodilator, and anti-aggregatory activities, as well as for their metabolic stability in human serum and whole blood. The results showed their potency and selectivity in inhibiting the COX isoforms, evaluated in whole human blood, as well as their anti-aggregatory activity to depend closely on the position at which the NO-donor moiety is introduced. All products dilated rat aorta strips precontracted with phenylephrine in a dose-dependent manner through a cGMP-dependent mechanism. They were stable in human serum while, in blood, they were metabolically transformed, principally to the related alcohols.
}

Introduction. - Cyclooxygenase (COX) is one of the key enzymes implicated in the transformation of arachidonic acid into prostanoids. It exists in at least two isoforms, COX -1 and COX -2 . The former is prevalently a constitutive and the latter an inducible isoform. Selective blocking of these isoforms induces specific pharmacological effects which can be exploited in therapy [1]. COX-2-Selective inhibitors (Coxibs) are a new class of drugs recently introduced into the market [2]; they induce anti-inflammatory effects without the gastrotoxic side-effects typical of the classical non-steroidal antiinflammatory drugs (NSAIDs), which are nonselective COX inhibitors. An interesting aspect of these drugs is their potential use in treating Alzheimer's disease and certain forms of cancer [3] [4]. The drawback in their use is that they increase the risk of heart attack and stroke [5][6]. Blood vessels and platelets are the major targets of prostanoids such as prostacycline $\mathrm{PGI}_{2}$, prostaglandin $\mathrm{PGE}_{2}$, and thromboxane $\mathrm{Tx} \mathrm{A}_{2}$ in the cardiovascular system. The proaggregatory and vasoconstrictor $\mathrm{TxA}_{2}$ is mainly synthesized via $\mathrm{COX}-1$ in the platelets, while vasodilator $\left(\mathrm{PGI}_{2}, \mathrm{PGE}_{2}\right)$ and antiplatelet $\left(\mathrm{PGI}_{2}\right)$ compounds are synthesized mainly in the vascular endothelium. A strategy to improve the benefit-risk profiles of these drugs is to design a multi-target drug by combining COX-2-selective inhibition with nitric oxide (NO)-dependent activities. NO displays a variety of effects in the cardiovascular system, including vasodilation, inhibition of platelet aggregation, modulation of platelet and leukocytes adherence to vessels, and inhibition of smooth muscle cell proliferation [7]. Examples of this type of approach have already been reported [8][9] including by our group [10][11]. As a development of our work in this field, we now describe the synthesis and structural characterization of a new series of NO-donor COX-2 inhibitors obtained by introducing NO-donor nitrooxy functions into the well-known selective COX-2 
inhibitor celecoxib (1) [12] that has recently been placed under surveillance by FDA, following its suspected cardiotoxicity.

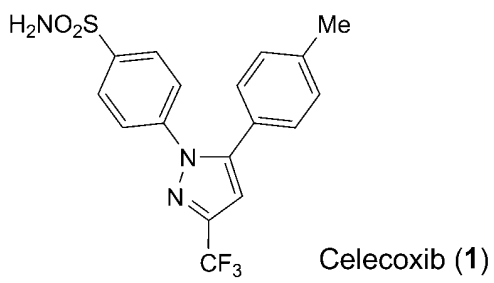

The results of a preliminary pharmacological screening of these new hybrid products and of their alcoholic metabolites show that their potency and selectivity in inhibiting the COX isoforms, evaluated in whole human blood, is closely dependent on the position at which the NO-donor moiety is introduced. This aspect is discussed, as well as the NO-dependent ability of the products to relax rat aorta strips precontracted with phenylephrine and, for selected compounds, their capacity to inhibit collageninduced platelet aggregation of human platelet rich plasma (PRP).

Results and Discussion. -1 . Chemistry. The general strategy for the synthesis of the nitrooxy substituted celecoxib derivatives 7, 11, and $\mathbf{1 5}$ is outlined in Schemes 1 and 2. The trifluoromethyl $\beta$-diketone 4 was obtained by refluxing 4-(hydroxymethyl)acetophenone (2) and ethyl trifluoroacetate in $\mathrm{MeOH}$ in the presence of MeONa. The intermediate 4 was isolated but not purified, since it was immediately condensed in refluxing EtOH with the hydrochloride of the phenylhydrazine derivative $\mathbf{5}$ to give, with a fair yield, the 1,5-diphenyl- $1 H$-pyrazole derivative $\mathbf{6}$, accompanied by a small amount of the 1,3-diphenyl isomer. This is in keeping with reports that 1,5-diarylpyrazole derivatives are almost exclusively produced, when the hydrochloride salt of the phenylhydrazine is condensed with trifluoromethyl $\beta$-diketones in refluxing EtOH or $\mathrm{MeOH}$ [13]. Treatment of $\mathbf{6}$ dissolved in $\mathrm{MeCN}$ with $N$-bromosuccinimide (NBS) in the presence of $\mathrm{Ph}_{3} \mathrm{P}$ and $\mathrm{AgNO}_{3}$ afforded a crude product that was purified by flash chromatography to give the expected final compound 7, mononitrooxymethylsubstituted at the 5-phenyl group. When $\mathbf{4}$ underwent reaction with the hydrochloride salt of phenylhydrazine derivative $\mathbf{8}$, it produced the pyrazolylbenzoate $\mathbf{9}$ in a highly regiospecific manner. Reduction of the ester function of 9 with $\mathrm{LiAlH}_{4}$ yielded the dimethanol 10, which was transformed into the final dinitrooxy derivative $\mathbf{1 1}$ according to the same procedure used to prepare 7 from $\mathbf{6}$. This reaction was accompanied by the formation of small amounts of a mixture of the two isomeric mononitrooxy alcohols 11a and 11b in a ratio of $c a .1: 1$ (NMR detection). When $\mathbf{8}$ was allowed to react in refluxing $\mathrm{MeOH}$ with the trifluoromethyl $\beta$-diketone 12, obtained from the commercially available 4-methylacetophenone (3), the 1,5-diphenylpyrazole derivative $\mathbf{1 3}$ was yielded in a moderately regiospecific manner. This product was separated by flash chromatography from a minor amount of 1,3-diphenyl isomer and transformed into the final mononitrooxy derivative 15, through the intermediate formation of the alcohol 14, following the sequence of reactions used to prepare $\mathbf{1 1}$ from $\mathbf{9}$. 
Scheme 1

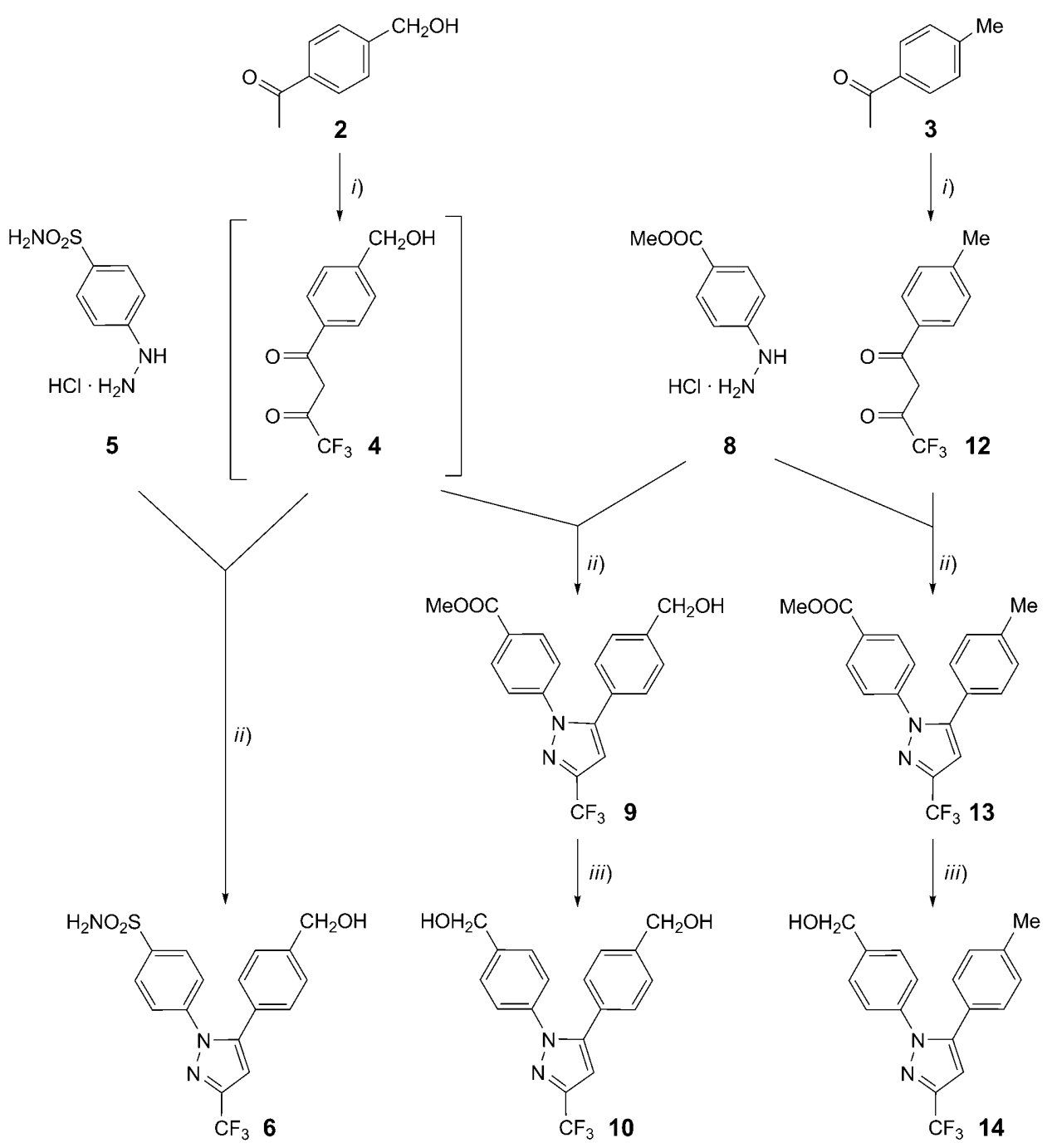

i) $\mathrm{MeONa}, \mathrm{CF}_{3} \mathrm{COOEt}, \mathrm{MeOH}$, reflux. ii) Refluxing in $\mathrm{MeOH}$ (in EtOH for 6). iii) $\mathrm{LiAlH}_{4}, \mathrm{THF}$.

2. Stability in Human Serum and in Human Whole Blood. It is known that nitrates can undergo chemical and enzymatic metabolism [14]. Celecoxib (1) and its derivatives were found to be stable following $24 \mathrm{~h}$ incubation in human serum. By contrast, derivatives 7, 11, and $\mathbf{1 5}$ were extensively metabolized when incubated in whole human blood. This transformation was monitored by RP-HPLC. The half-lives $\left(t_{1 / 2}\right)$ are reported in Table 1. Products 11 and $\mathbf{1 5}$ behaved similarly, while $\mathbf{7}$ surprisingly did not: its $t_{1 / 2}$ is $c a .1 \mathrm{~h}, v s .25-30 \mathrm{~h}$ of the other compounds, and after $24 \mathrm{~h}$ only $4.5 \%$ of the original product remained unchanged. Compounds $\mathbf{1 1}$ and $\mathbf{1 5}$ were principally 
Scheme 2

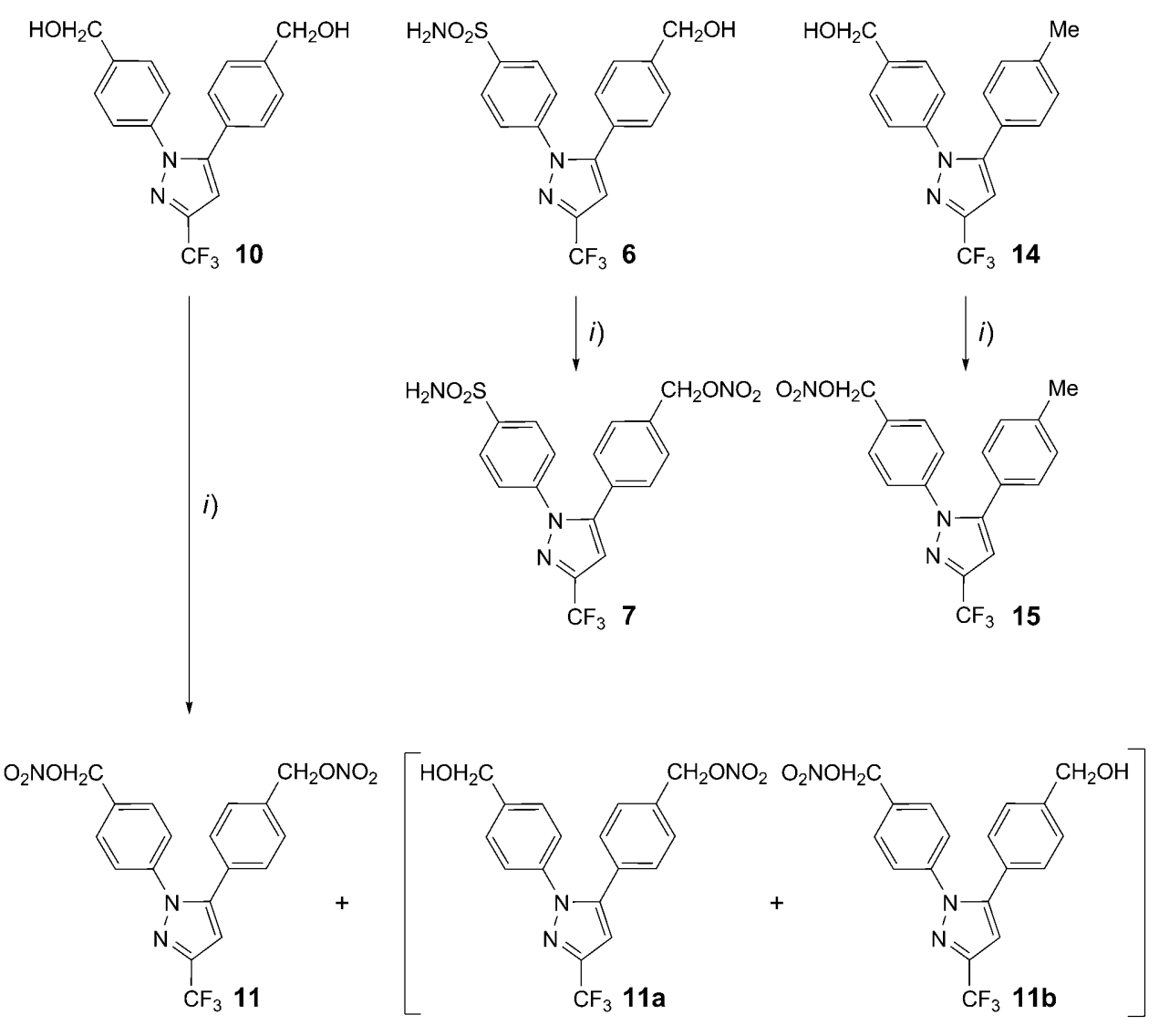

i) $\mathrm{Ph}_{3} \mathrm{P}, \mathrm{AgNO}_{3}, N$-bromosuccinimide (NBS), $-15^{\circ} \rightarrow$ r.t.

transformed into the corresponding alcohols $\mathbf{1 0}, \mathbf{1 1 a} / \mathbf{1 1 b}$ and $\mathbf{1 4}$, respectively (Table 1). These metabolites were identified by comparison of their retention times with those of alcohols $\mathbf{1 0}$ and 14, which were used as intermediates to prepare the final compounds. Similarly, the mixture 11a/11b was used as reference to identify the two isomeric mononitrooxy alcohols that derive from the biotransformation of $\mathbf{1 1}$. The behavior of

Table 1. Whole Human Blood Stability

\begin{tabular}{lccr}
\hline Compound & $\begin{array}{l}\text { \% of unchanged compound } \\
\text { after } 24 \mathrm{~h}( \pm \mathrm{SEM})\end{array}$ & $\begin{array}{l}\text { \% of alcoholic metabolites } \\
\text { after } 24 \mathrm{~h}( \pm \mathrm{SEM})\end{array}$ & $t_{1 / 2}[\mathrm{~h}]$ \\
\hline $\mathbf{1}$ & 100 & & \\
$\mathbf{7}$ & $4.5 \pm 1.1$ & $4.5 \pm 0.5(\mathbf{6})$ & 0.8 \\
$\mathbf{1 1}$ & $59.4 \pm 4.4$ & $16.2 \pm 0.7$ of $\mathbf{1 1 a} / \mathbf{1 1 b}$ & 30.0 \\
$\mathbf{1 5}$ & $54.4 \pm 2.3$ & $11.7 \pm 1.0$ of $\mathbf{1 0}$ & 25.4 \\
\hline
\end{tabular}


compound 7 again differed: HPLC analysis, using the alcohol $\mathbf{6}$ as standard, revealed only $4.5 \%$ of this product as detectable metabolite. This indicates that the other metabolites formed are not free in the cytosol, but they are sequestrated by components of the blood compartment.

3. COX Inhibition. The ability of the products and of their alcoholic metabolites to inhibit the COX enzymes was evaluated in human whole blood according to an established procedure [15]. To assay the extent of COX-2 isoform inhibition, human heparinized whole blood was incubated with lipopolysaccharide (LPS) overnight in the presence of the inhibitors, and plasma reduction of $\mathrm{PGE}_{2}$ production in comparison with control samples was assayed as a function of COX-2 inhibition. For COX-1 inhibition, whole blood samples without any anticoagulant were incubated with the inhibitors for $1 \mathrm{~h}$; serum was then collected and analyzed for $\mathrm{TxB}_{2}$ production. The potencies of the products are expressed as $I C_{50}$ (Table 2); when this could not be calculated because inhibition did not reach $50 \%$, inhibition at the maximum concentration tested $(100 \mu \mathrm{M})$ is reported.

Table 2. COX-1 and COX-2 Inhibition Data for Compounds and Celecoxib (1) Taken as Reference

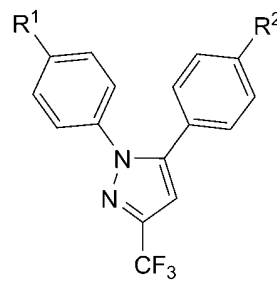

\begin{tabular}{|c|c|c|c|c|c|}
\hline \multirow[t]{2}{*}{ Compound } & \multirow[t]{2}{*}{$\mathbf{R}^{1}$} & \multirow[t]{2}{*}{$\mathrm{R}^{2}$} & \multicolumn{2}{|l|}{ COX-1 } & \multirow{2}{*}{$\frac{\mathrm{COX}-2}{I C_{50} \pm \mathrm{SE}[\mu \mathrm{M}]}$} \\
\hline & & & $I C_{50} \pm \mathrm{SE}[\mu \mathrm{M}]$ & $\%$ Inhibition \pm SE $\left.\left(100 \mu \mathrm{M}^{\mathrm{a}}\right)\right)$ & \\
\hline 1 & $\mathrm{SO}_{2} \mathrm{NH}_{2}$ & $\mathrm{Me}$ & $14 \pm 2$ & - & $1.3 \pm 0.4$ \\
\hline 6 & $\mathrm{SO}_{2} \mathrm{NH}_{2}$ & $\mathrm{CH}_{2} \mathrm{OH}$ & b) & $20 \pm 13$ & $52 \pm 3$ \\
\hline 7 & $\mathrm{SO}_{2} \mathrm{NH}_{2}$ & $\mathrm{CH}_{2} \mathrm{ONO}_{2}$ & b) & $6.7 \pm 3.8$ & $67 \pm 19$ \\
\hline 10 & $\mathrm{CH}_{2} \mathrm{OH}$ & $\mathrm{CH}_{2} \mathrm{OH}$ & $0.51 \pm 0.14$ & - & $12 \pm 3$ \\
\hline 11 & $\mathrm{CH}_{2} \mathrm{ONO}_{2}$ & $\mathrm{CH}_{2} \mathrm{ONO}_{2}$ & b) & $15 \pm 7$ & $19 \pm 1$ \\
\hline 14 & $\mathrm{CH}_{2} \mathrm{OH}$ & $\mathrm{Me}$ & $0.41 \pm 0.08$ & - & $11 \pm 3$ \\
\hline 15 & $\mathrm{CH}_{2} \mathrm{ONO}_{2}$ & $\mathrm{Me}$ & $4.6 \pm 1.6$ & - & $31 \pm 10$ \\
\hline
\end{tabular}

a) Maximum concentration tested. ${ }^{b}$ ) Inhibition of control $\mathrm{TxB}_{2}$ production did not reach $50 \%$.

The data show that product 7, derived from substituting the nitrooxymethyl function for the methyl group of celecoxib (1), is a feeble COX-2 inhibitor, being ca. 50 times less potent than the lead, but that it retains a good degree of COX-2 selectivity: it displayed negligible COX-1 activity when tested at $100 \mu \mathrm{M}$ concentration. Its alcoholic metabolite 6 behaves similarly. When it is the aminosulfonyl group that is substituted, which is an important determinant for the COX-2 selectivity of $\mathbf{1}$ [16], 15 is obtained, which is a more potent COX-1 inhibitor than $\mathbf{1}$, and which displays a rather good COX1 selectivity. COX-1 Inhibition potency and selectivity are even more evident in its alcoholic metabolite 14. Finally, the simultaneous substitution of both the Me and the 
aminosulfonyl moiety in $\mathbf{1}$ provides $\mathbf{1 1}$, which is a fairly potent COX-2 inhibitor, with negligible COX-1 activity when tested at a concentration of $100 \mu \mathrm{M}$. By contrast, its dihydroxy metabolite $\mathbf{1 0}$ shows a COX-inhibitory profile very close to that of $\mathbf{1 4}$. All compounds were also tested for their ability to inhibit collagen-induced platelet aggregation of human platelet rich plasma (PRP). The products $\mathbf{1 0}$ and $\mathbf{1 4}$ display antiplatelet action in the $\mu \mathrm{M}$ range (Table 3 ) in keeping with their ability to inhibit the COX-1 isoform. Also the activity of the NO donor $\mathbf{1 5}$ is essentially COX-1- and not NO-dependent, in agreement with the reduced ability of platelets to effect NO release from organic nitrates [17]. Indeed, the anti-aggregatory potency of this compound was not modified by the presence of ODQ $(1 H$-[1,2,4] oxadiazolo[4,3-a]quinoxalin-1-one), a well-known inhibitor of the soluble guanylate cyclase (sGC).

Table 3. Anti-Aggregatory and Vasodilating Properties of Derivatives

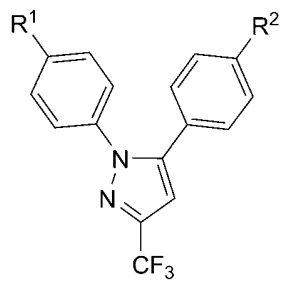

\begin{tabular}{|c|c|c|c|c|c|}
\hline \multirow[t]{2}{*}{ Compound } & \multirow[t]{2}{*}{$\mathrm{R}^{1}$} & \multirow[t]{2}{*}{$\mathrm{R}^{2}$} & \multicolumn{2}{|c|}{ Anti-aggregatory activity } & \multirow{2}{*}{$\frac{\text { Vasodilating activity }}{E C_{50} \pm \mathrm{SE}[\mu \mathrm{M}]}$} \\
\hline & & & $\begin{array}{l}I C_{50}(95 \% \mathrm{CL}) \\
{[\mu \mathrm{M}]}\end{array}$ & $\begin{array}{l}\% \text { inhibition } \pm S E \\
\left.\left(100 \mu \mathrm{M}^{\mathrm{a}}\right)\right)\end{array}$ & \\
\hline 1 & $\mathrm{SO}_{2} \mathrm{NH}_{2}$ & $\mathrm{Me}$ & $31(25-39)$ & - & - \\
\hline 6 & $\mathrm{SO}_{2} \mathrm{NH}_{2}$ & $\mathrm{CH}_{2} \mathrm{OH}$ & b) & $5.8 \pm 2.1$ & - \\
\hline 7 & $\mathrm{SO}_{2} \mathrm{NH}_{2}$ & $\mathrm{CH}_{2} \mathrm{ONO}_{2}$ & b) & $3.4 \pm 2.6$ & $\begin{array}{l}0.26 \pm 0.05 \\
\left.7.0 \pm 1.3^{\mathrm{c}}\right)\end{array}$ \\
\hline 10 & $\mathrm{CH}_{2} \mathrm{OH}$ & $\mathrm{CH}_{2} \mathrm{OH}$ & $8.4(7.0-10)$ & - & - \\
\hline 11 & $\mathrm{CH}_{2} \mathrm{ONO}_{2}$ & $\mathrm{CH}_{2} \mathrm{ONO}_{2}$ & b) & $7.4 \pm 4.3$ & $\begin{array}{l}0.10 \pm 0.03 \\
\left.26 \pm 9^{c}\right)\end{array}$ \\
\hline 14 & $\mathrm{CH}_{2} \mathrm{OH}$ & $\mathrm{Me}$ & $11(10-12)$ & - & - \\
\hline 15 & $\mathrm{CH}_{2} \mathrm{ONO}_{2}$ & $\mathrm{Me}$ & $\left.48(44-52)^{\mathrm{d}}\right)$ & - & $\begin{array}{l}0.12 \pm 0.01 \\
\left.>100^{c}\right)\end{array}$ \\
\hline $\left.\operatorname{ISDN}^{\mathrm{e}}\right)$ & & & & & $\begin{array}{l}4.7 \pm 0.6 \\
\left.>100^{c}\right)\end{array}$ \\
\hline
\end{tabular}

a) Maximum concentration tested. ${ }^{b}$ ) Inhibition of control aggregation effect did not reach $50 \%{ }^{c}$ ) In the presence of $1 \mu \mathrm{M}$ ODQ. ${ }^{\mathrm{d}}$ ) Unchanged in the presence of $100 \mu \mathrm{M}$ ODQ. ${ }^{\mathrm{e}}$ ) Isosorbide dinitrate.

4. Vasodilation. The in vitro vasodilating activities of this new series of COX inhibitors was assessed on rat aorta strips precontracted with phenylephrine. All products relaxed the contracted tissues in a concentration-dependent manner. Their potencies, expressed as $E C_{50}$, are shown in Table 3. All act as potent vasodilators, their potencies being closely distributed in the submicromolar range. Vasodilating potencies markedly decreased, when the experiments were repeated in the presence of $1 \mu \mathrm{M}$ 
ODQ. This is typical of the classical nitrooxy-containing compounds, such as isosorbide dinitrate (ISDN), which was used as reference.

Conclusions. - Introduction at the para-position of the phenyl rings present in celecoxib (1) of either the nitrooxymethyl group or the hydroxymethyl group, deriving from its metabolic transformation, gives rise to a complex behavior. When these moieties are linked to the $N$-phenyl ring, the selective and potent COX-1 inhibitors 14 and 15, endowed with anti-aggregatory activity, are obtained. By contrast, when they are attached to the $C$-phenyl group, the selective but weak COX-2 inhibitors 6 and 7 are generated. Interesting results occurred following the simultaneous introduction of either two nitrooxy or two hydroxymethyl functions on the two phenyl groups. In the former case, the fairly potent and selective COX-2 inhibitor 11, endowed with a feeble anti-aggregatory activity, was obtained, while, in the latter case, compound $\mathbf{1 0}$ was obtained, which is a potent and selective COX-1 inhibitor endowed with a high antiaggregatory activity. All of the products containing nitrooxy moieties displayed NOdependent vasodilatory activity. Compound $\mathbf{1 1}$ emerges as the most interesting product arising from these chemical manipulations of compound $\mathbf{1}$, in terms of the possibility of producing a COX-2-selective inhibitor potentially possessing low cardiotoxicity.

This work was supported by a MIUR grant (COFIN 2005).

\section{Experimental Part}

General. Compounds 2 [18], 5 [19], 8 [20], and $\mathbf{1 2}$ [12] were synthesized according to the methods described in the literature. THF was distilled immediately before use from $\mathrm{Na}$ and benzophenone. Anh. $\mathrm{MgSO}_{4}$ was used as drying agent for the org. phases. Flash column chromatography (FC): silica gel (Merck Kieselgel 60, 230-400 mesh ASTM) with the eluents indicated. TLC: $5 \times 20 \mathrm{~cm}$ plates with 0.25mm layer thickness. M.p.: cap. apparatus (Büchi 540); m.p. with decomposition were determined after placing the sample in a bath at a temp. $10^{\circ}$ below the m.p.; a heating rate of $1^{\circ} \mathrm{min}^{-1}$ was used. FT-IR: Perkin-Elmer SPECTRUM BXII. ${ }^{1} \mathrm{H}-$ and ${ }^{13} \mathrm{C}-\mathrm{NMR}$ : Bruker Avance-300. MS: Finnigan-Mat TSO-700. Analysis $(\mathrm{C}, \mathrm{H}, \mathrm{N})$ of the new compounds was performed by REDOX $($ Monza $)$ and the results are within $\pm 0.4 \%$ of the theoretical values.

4,4,4-Trifluoro-1-[4-(hydroxymethyl)phenyl]butane-1,3-dione (4). 1.5M $\mathrm{MeONa}$ in $\mathrm{MeOH}(5 \mathrm{ml}$, $7.5 \mathrm{mmol}$ ) was added to a soln. of 4-(hydroxymethyl)acetophenone (2) $(0.72 \mathrm{~g}, 4.8 \mathrm{mmol})$ in dry $\mathrm{MeOH}$ $(4 \mathrm{ml})$. The mixture was stirred for $5 \mathrm{~min}$, after which ethyl trifluoroacetate $(0.7 \mathrm{ml}, 7.0 \mathrm{mmol})$ was added. After refluxing for $24 \mathrm{~h}$, the mixture was cooled to r.t. and concentrated in vacuo; $10 \% \mathrm{HCl}(10 \mathrm{ml})$ was added, and the mixture was extracted with AcOEt. The extracts were dried and concentrated to afford 4 as a brown oil $(0.99 \mathrm{~g})$, which was used without further purification.

4-\{5-[4-(Hydroxymethyl)phenyl]-3-(trifluoromethyl)-1H-pyrazol-1-yl\}benzenesulfonamide (6). (4Sulfamoylphenyl)hydrazine hydrochloride $(5 ; 0.93 \mathrm{~g}, 4.2 \mathrm{mmol})$ was added to a stirred soln. of $4(0.99 \mathrm{~g})$ in EtOH $(50 \mathrm{ml})$. The mixture was heated to reflux for $24 \mathrm{~h}$. After cooling to r.t., the mixture was concentrated in vacuo, the residue was taken up in AcOEt, washed with $\mathrm{H}_{2} \mathrm{O}$ and brine, dried, and concentrated in vacuo to give an oil that was purified by FC (petroleum ether ( $\mathrm{PE}$ )/i-PrOH 9:1) to give 6 $(0.95 \mathrm{~g}, 57 \%)$. Pale yellow solid. M.p. $157-158^{\circ}$ (from benzene). ${ }^{1} \mathrm{H}-\mathrm{NMR}\left(\mathrm{CDCl}_{3}\right): 7.84(d, J=8.6,2$ arom. $\mathrm{H}) ; 7.41(d, J=8.6,2$ arom. $\mathrm{H}) ; 7.34(d, J=8.1,2$ arom. $\mathrm{H}) ; 7.20(d, J=8.1,2$ arom. $\mathrm{H}) ; 6.76(s, \mathrm{CH}$ (pyrazole)); $5.31\left(s, \mathrm{NH}_{2}\right) ; 4.69\left(s, \mathrm{CH}_{2}\right) ; 2.06$ (br. $\left.s, \mathrm{OH}\right) .{ }^{13} \mathrm{C}-\mathrm{NMR}\left(\mathrm{CDCl}_{3}\right): 144.9 ; 144.2\left(q,{ }^{2} J=38\right)$; $142.4 ; 142.3 ; 141.5 ; 129.0 ; 127.7 ; 127.5 ; 127.4 ; 125.6 ; 121.0\left(q,{ }^{1} J=268\right) ; 106.6\left(q,{ }^{3} J=2\right) ; 64.5$. CI-MS (i$\mathrm{Bu}): 398\left([M+1]^{+}\right)$. Anal. calc. for $\mathrm{C}_{17} \mathrm{H}_{14} \mathrm{~F}_{3} \mathrm{~N}_{3} \mathrm{O}_{3} \mathrm{~S}(397.38)$ : C 51.38, H 3.55, N 10.57; found C 51.68, $\mathrm{H}$ $3.66, \mathrm{~N} 10.52$. 
Methyl 4-\{5-[4-(Hydroxymethyl)phenyl]-3-(trifluoromethyl)-1H-pyrazol-1-yl\}benzoate (9). [4-(Methoxycarbonyl)phenyl]hydrazine hydrochloride $(\mathbf{8} ; 0.84 \mathrm{~g}, 4.2 \mathrm{mmol})$ was added to a stirred soln. of 4 $(0.99 \mathrm{~g})$ in $\mathrm{MeOH}(40 \mathrm{ml})$. The mixture was heated to reflux for $3 \mathrm{~h}$. After cooling to r.t., the mixture was concentrated in vacuo, the residue was taken up in AcOEt, washed with $\mathrm{H}_{2} \mathrm{O}$ and brine, dried, and concentrated in vacuo to give an oil that was purified by $\mathrm{FC}\left(\mathrm{CH}_{2} \mathrm{Cl}_{2} / \mathrm{AcOEt} 99\right.$ :1) to give $9(0.73 \mathrm{~g}$, $46 \%)$. Yellow solid. M.p. $95-97^{\circ}\left(\right.$ dec.; i- $\left.\mathrm{Pr}_{2} \mathrm{O}\right) .{ }^{1} \mathrm{H}-\mathrm{NMR}\left(\mathrm{CDCl}_{3}\right): 8.02(d, J=8.6,2$ arom. $\mathrm{H}) ; 7.39(d$, $J=8.6,2$ arom. $\mathrm{H}) ; 7.34(d, J=8.1,2$ arom. $\mathrm{H}) ; 7.21(d, J=8.1,2$ arom. $\mathrm{H}) ; 6.76(s, \mathrm{CH}$ (pyrazole $)) ; 4.71(s$, $\left.\mathrm{CH}_{2}\right) ; 3.92(s, \mathrm{Me}) ; 2.15$ (br. $\left.s, \mathrm{OH}\right) .{ }^{13} \mathrm{C}-\mathrm{NMR}\left(\mathrm{CDCl}_{3}\right): 166.1 ; 144.8 ; 143.9\left(q,{ }^{2} J=38\right) ; 142.7 ; 142.3$; $130.6 ; 130.0 ; 129.8 ; 128.0 ; 127.2 ; 125.0 ; 121.1\left(q,{ }^{1} J=267\right) ; 106.3\left(q,{ }^{3} J=2\right) ; 64.5 ; 52.4$. CI-MS (i-Bu): 377 $\left([M+1]^{+}\right)$. Anal. calc. for $\mathrm{C}_{19} \mathrm{H}_{15} \mathrm{~F}_{3} \mathrm{~N}_{2} \mathrm{O}_{3}$ (376.34): C 60.64, $\mathrm{H}$ 4.02, N 7.44; found: C 60.87, H 4.40, N 7.40.

Methyl 4-[5-(4-Methylphenyl)-3-(trifluoromethyl)-1H-pyrazol-1-yl]benzoate (13). Compound 8 $(3.41 \mathrm{~g}, 17.0 \mathrm{mmol})$ was added to a stirred soln. of $\mathbf{1 2}(3.87 \mathrm{~g}, 17.0 \mathrm{mmol})$ in $\mathrm{MeOH}(100 \mathrm{ml})$. The mixture was heated to reflux for $20 \mathrm{~h}$. After cooling to r.t., the mixture was concentrated in vacuo, the residue was taken up in AcOEt, washed with $\mathrm{H}_{2} \mathrm{O}$ and brine, dried, and concentrated in vacuo to give an oil that was purified by FC (PE/AcOEt 97:3) to give $\mathbf{1 3}(2.06 \mathrm{~g}, 34 \%)$. White solid. M.p. $78.5-79.5^{\circ}$ (hexane). ${ }^{1} \mathrm{H}-\mathrm{NMR}\left(\mathrm{CDCl}_{3}\right): 8.03(d, J=8.6,2$ arom. $\mathrm{H}) ; 7.39(d, J=8.6,2$ arom. $\mathrm{H}) ; 7.16-7.08(m, 4$ arom. H); 6.73 ( $s, \mathrm{CH}$ (pyrazole)); $3.92(s, \mathrm{MeO}) ; 2.36$ (br. $s, \mathrm{Me}) .{ }^{13} \mathrm{C}-\mathrm{NMR}\left(\mathrm{CDCl}_{3}\right): 166.2 ; 145.2 ; 143.9$ $\left(q,{ }^{2} J=38\right) ; 142.8 ; 139.6 ; 130.6 ; 129.8 ; 129.7 ; 128.8 ; 126.1 ; 125.1,121.3\left(q,{ }^{1} J=267\right) ; 106.1\left(q,{ }^{3} J=2\right) ; 52.5$; 21.4. EI-MS: $360\left(100, M^{+}\right), 329$ (50). Anal. calc. for $\mathrm{C}_{19} \mathrm{H}_{15} \mathrm{~F}_{3} \mathrm{~N}_{2} \mathrm{O}_{2}$ (360.34): C 63.33, H 4.20, N 7.77; found: C $63.95, \mathrm{H} 4.13, \mathrm{~N} 7.81$.

4-\{1-[4-(Hydroxymethyl)phenyl]-3-(trifluoromethyl)-1H-pyrazol-1-yl\}phenylmethanol (10). A soln. of $9(1.26 \mathrm{~g}, 3.4 \mathrm{mmol})$ in dry THF $(10 \mathrm{ml})$ was added dropwise to a stirred mixture of $\mathrm{LiAlH}_{4}(0.13 \mathrm{~g}$, $3.4 \mathrm{mmol})$ in dry THF $(10 \mathrm{ml})$ under $\mathrm{N}_{2}$. After $30 \mathrm{~min}, \mathrm{H}_{2} \mathrm{O}(1 \mathrm{ml}), \mathrm{NaOH} 15 \%(1 \mathrm{ml})$, and $\mathrm{H}_{2} \mathrm{O}(1 \mathrm{ml})$ were added sequentially to the mixture, after which the solid was filtered and washed with $\mathrm{MeOH}$. The filtrate was concentrated in vacuo, and the residue was taken up in AcOEt, washed with $\mathrm{H}_{2} \mathrm{O}$ and brine, dried, and concentrated in vacuo to give an oil that was purified by $\mathrm{FC}\left(\mathrm{CH}_{2} \mathrm{Cl}_{2} / \mathrm{AcOEt} 8: 2\right)$ to give $\mathbf{1 0}$ $(0.70 \mathrm{~g}, 59 \%)$. White solid. M.p. $107-111^{\circ}\left(\mathrm{i}-\mathrm{Pr}_{2} \mathrm{O}\right) .{ }^{1} \mathrm{H}-\mathrm{NMR}\left(\mathrm{CDCl}_{3}\right): 7.35-7.26(\mathrm{~m}, 6$ arom. $\mathrm{H}) ; 7.21(d$, $J=8.1,2$ arom. $\mathrm{H}) ; 6.74(s, \mathrm{CH}$ (pyrazole) $) ; 4.70\left(s, 2 \mathrm{CH}_{2}\right) ; 1.98$ (br. $\left.s, \mathrm{OH}\right) ; 1.90$ (br. $\left.s, \mathrm{OH}\right) .{ }^{13} \mathrm{C}-\mathrm{NMR}$ $\left(\mathrm{CDCl}_{3}\right)$ : $144.5 ; 143.2\left(q,{ }^{2} J=38\right), 141.8 ; 141.3 ; 138.3 ; 128.9 ; 128.3 ; 127.4 ; 127.1 ; 125.6 ; 121.2\left(q,{ }^{1} J=267\right)$; 105.6 $\left(q,{ }^{3} J=2\right) ; 64.6 ; 64.4$. CI-MS (i-Bu): $349(M+1)^{+}$. Anal. calc. for $\mathrm{C}_{18} \mathrm{H}_{15} \mathrm{~F}_{3} \mathrm{~N}_{2} \mathrm{O}_{2}(348.32): \mathrm{C} 62.07, \mathrm{H}$ 4.34, N 8.04; found: C 62.45, H 4.42, N 7.94 .

4-[5-(4-Methylphenyl)-3-(trifluoromethyl)-1H-pyrazol-1-yl]phenylmethanol (14). A soln. of $\mathbf{1 3}$ $(2.18 \mathrm{~g}, 6.0 \mathrm{mmol})$ in dry THF $(25 \mathrm{ml})$ was added dropwise to a stirred mixture of $\mathrm{LiAlH}_{4}(0.23 \mathrm{~g}$, $6.0 \mathrm{mmol})$ in dry THF $(25 \mathrm{ml})$ under $\mathrm{N}_{2}$. After $30 \mathrm{~min}, \mathrm{H}_{2} \mathrm{O}(1 \mathrm{ml}), \mathrm{NaOH} 15 \%(1 \mathrm{ml})$ and $\mathrm{H}_{2} \mathrm{O}(1 \mathrm{ml})$ were added sequentially to the mixture, then the solid was filtered and washed with $\mathrm{MeOH}$. The filtered soln. was concentrated in vacuo, and the residue was taken up in AcOEt, washed with $\mathrm{H}_{2} \mathrm{O}$ and brine, dried, and concentrated in vacuo to give a solid $(1.91 \mathrm{~g}, 96 \%)$ that was purified by crystallization from EtOH/ $\mathrm{H}_{2} \mathrm{O}$ to give 14. White solid. M.p. $109-111^{\circ}\left(\mathrm{EtOH} / \mathrm{H}_{2} \mathrm{O}\right) .{ }^{1} \mathrm{H}-\mathrm{NMR}\left(\mathrm{CDCl}_{3}\right): 7.35-7.27(\mathrm{~m}, 4$ arom. H); $7.11-7.09(m, 4$ arom. $\mathrm{H}) ; 6.71(s, \mathrm{CH}$ (pyrazole) $) ; 4.70\left(s, \mathrm{CH}_{2}\right) ; 2.34(s, \mathrm{Me}) ; 1.93$ (br. $\left.s, \mathrm{OH}\right)$. ${ }^{13} \mathrm{C}-\mathrm{NMR}\left(\mathrm{CDCl}_{3}\right): 144.8 ; 143.2\left(q,{ }^{2} J=38\right) ; 141.2 ; 139.1 ; 138.5 ; 129.4 ; 128.7 ; 127.3 ; 126.2 ; 125.5 ; 121.3(q$, $\left.{ }^{1} J=267\right) ; 105.3\left(q,{ }^{3} J=2\right)$; 64.4, 21.3. EI-MS: $332\left(100, M^{+}\right)$. Anal. calc. for $\mathrm{C}_{18} \mathrm{H}_{15} \mathrm{~F}_{3} \mathrm{~N}_{2} \mathrm{O}(332.32)$ : C 65.06, H 4.55, N 8.43; found: C 65.12, H 4.53, N 8.33.

4-\{1-[4-(Aminosulfonyl)phenyl]-3-(trifluoromethyl)-1H-pyrazol-5-yl\}benzyl Nitrate (7). $\mathrm{AgNO}_{3}$ $(1.00 \mathrm{~g}, 5.8 \mathrm{mmol})$ and $\mathrm{Ph}_{3} \mathrm{P}(0.75 \mathrm{~g}, 2.9 \mathrm{mmol})$ were added to a soln. of $6(1.00 \mathrm{~g}, 2.5 \mathrm{mmol})$ in $\mathrm{MeCN}$ $(30 \mathrm{ml})$ under $\mathrm{N}_{2}$. The mixture was cooled to $0^{\circ}$, and NBS $(0.50 \mathrm{~g}, 2.8 \mathrm{mmol})$ was added portionwise. Stirring was continued at $0^{\circ}$ for $1 \mathrm{~h}$ and then at r.t. for $3 \mathrm{~h}$. AcOEt was added to the mixture, and the solid was filtered; the filtrate was washed with $\mathrm{H}_{2} \mathrm{O}$, brine, dried, and concentrated in vacuo to give a solid that was purified by FC (PE/AcOEt $7: 3)$ to give $7(0.76 \mathrm{~g}, 70 \%)$. White solid. ${ }^{1} \mathrm{H}-\mathrm{NMR}\left(\left(\mathrm{D}_{6}\right) \mathrm{DMSO}\right): 7.89(d$, $J=8.6,2$ arom. $\mathrm{H}) ; 7.58-7.51\left(m, 4\right.$ arom. $\left.\mathrm{H}, \mathrm{NH}_{2}\right) ; 7.39(d, J=8.3,2$ arom. $\mathrm{H}) ; 7.30(s, \mathrm{CH}$ of pyrazol); $5.60\left(s, \mathrm{CH}_{2}\right) \cdot{ }^{13} \mathrm{C}-\mathrm{NMR}\left(\left(\mathrm{D}_{6}\right) \mathrm{DMSO}\right): 144.5 ; 144.5 ; 142.2\left(q,{ }^{2} J=37\right) ; 140.9 ; 133.4 ; 129.5 ; 129.2 ; 129.0$; 126.8; 126.0; $121.2\left(q,{ }^{1} J=267\right) ; 106.7\left(q,{ }^{3} J=2\right) ; 74.3$. EI-MS: $442\left(40, M^{+}\right), 397(40), 302$ (100). Anal. calc. for $\mathrm{C}_{17} \mathrm{H}_{13} \mathrm{~F}_{3} \mathrm{~N}_{4} \mathrm{O}_{5} \mathrm{~S}$ (442.38): C 46.16, H 2.96, N 12.66; found: C 45.96, H 2.89, N 12.29. 
4-\{1-[4-(Nitrooxymethyl)phenyl]-3-(trifluoromethyl)-1H-pyrazol-5-yl\}benzyl Nitrate (11). $\mathrm{AgNO}_{3}$ $(1.03 \mathrm{~g}, 6 \mathrm{mmol})$ and $\mathrm{Ph}_{3} \mathrm{P}(1.31 \mathrm{~g}, 5 \mathrm{mmol})$ were added to a soln. of $\mathbf{1 0}(0.7 \mathrm{~g}, 2 \mathrm{mmol})$ in $\mathrm{MeCN}$ $(20 \mathrm{ml})$ under $\mathrm{N}_{2}$. The mixture was cooled to $-15^{\circ}$ under $\mathrm{N}_{2}$, and NBS $(0.89 \mathrm{~g}, 5 \mathrm{mmol})$ was added portionwise. Stirring was continued at $-15^{\circ}$ for $1 \mathrm{~h}$ and then at r.t. for $12 \mathrm{~h}$. AcOEt was added to the mixture, and the solid was filtered; the filtrate was washed with $\mathrm{H}_{2} \mathrm{O}$, brine and dried, and concentrated in vacuo to give an oil which was purified by FC (hexane/AcOEt $9: 1$ ). The first eluted compound was $\mathbf{1 1}$ $(0.42 \mathrm{~g}, 48 \%)$. White solid. M.p. $52-53^{\circ}\left(\mathrm{i}-\mathrm{Pr}_{2} \mathrm{O} / \mathrm{PE}\right) .{ }^{1} \mathrm{H}-\mathrm{NMR}\left(\mathrm{CDCl}_{3}\right): 7.43-7.25(\mathrm{~m}, 8$ arom. $\mathrm{H}) ; 6.78$ $(s, \mathrm{CH}$ (pyrazole $)) ; 5.44,5.43\left(2 s, 2 \mathrm{CH}_{2} \mathrm{ONO}_{2}\right) .{ }^{13} \mathrm{C}-\mathrm{NMR}\left(\mathrm{CDCl}_{3}\right): 143.9 ; 143.7\left(q,{ }^{2} J=38\right) ; 139.8$; $133.4 ; 132.7 ; 130.0 ; 129.8 ; 129.4 ; 129.4 ; 125.7 ; 121.1\left(q,{ }^{1} J=268\right) ; 106.3\left(q,{ }^{3} J=2\right) ; 73.9 ; 73.6$. EI-MS: 438 $\left(30, M^{+}\right), 345$ (48), $316(100)$. Anal. calc. for $\mathrm{C}_{18} \mathrm{H}_{13} \mathrm{~F}_{3} \mathrm{~N}_{4} \mathrm{O}_{6}$ (438.32): C 49.32, H 2.99, N 12.78; found: C $49.38, \mathrm{H} 2.95, \mathrm{~N} 12.56$.

The second eluted fraction was the mixture of the two mononitrate products 11a and 11b, obtained as a transparent oil. ${ }^{1} \mathrm{H}-\mathrm{NMR}\left(\mathrm{CDCl}_{3}\right): 7.41-7.20(\mathrm{~m}, 16$ arom. $\mathrm{H}) ; 6.75,6.77(2 s, 2 \mathrm{CH}$ (pyrazole)); 5.42, $5.43\left(2 s, 2 \mathrm{CH}_{2} \mathrm{ONO}_{2}\right) ; 4.73,4.72\left(2 s, 2 \mathrm{CH}_{2} \mathrm{OH}\right) ; 1.79$ (br. $\left.s, 2 \mathrm{OH}\right) .{ }^{13} \mathrm{C}-\mathrm{NMR}\left(\mathrm{CDCl}_{3}\right): 144.6 ; 143.8$; $143.4\left(q,{ }^{2} J=38\right) ; 142.1 ; 141.6 ; 140.0 ; 138.2 ; 133.1 ; 132.5 ; 130.3 ; 129.7 ; 129.3 ; 129.2 ; 129.0 ; 128.1 ; 127.5$; $127.2 ; 125.7 ; 125.6 ; 121.4\left(q,{ }^{1} J=268\right) ; 106.0\left(q,{ }^{3} J=2\right) ; 105.9\left(q,{ }^{3} J=2\right) ; 73.9 ; 73.7 ; 64.6 ; 64.4$. EI-MS: 393 $\left(97, M^{+}\right), 347(100), 317$ (99). Anal. calc. for $\mathrm{C}_{18} \mathrm{H}_{14} \mathrm{~F}_{3} \mathrm{~N}_{3} \mathrm{O}_{4}$ (393.32): C 54.97, H 3.59, N 10.68; found: C 55.44, H 3.94, N 10.30.

4-[5-(4-Methylphenyl)-3-(trifluoromethyl)-1H-pyrazol-1-yl]benzyl Nitrate (15). $\mathrm{AgNO}_{3}(0.68 \mathrm{~g}$, $4 \mathrm{mmol})$ and $\mathrm{Ph}_{3} \mathrm{P}(0.92 \mathrm{~g}, 3.5 \mathrm{mmol})$ were added to a soln. of $14(0.66 \mathrm{~g}, 2 \mathrm{mmol})$ in $\mathrm{MeCN}(30 \mathrm{ml})$ under $\mathrm{N}_{2}$. The mixture was cooled to $-15^{\circ}$ under $\mathrm{N}_{2}$, and NBS $(0.62 \mathrm{~g}, 3.5 \mathrm{mmol})$ was added portionwise. Stirring was continued at $-15^{\circ}$ for $1 \mathrm{~h}$ and then at r. t. for $4 \mathrm{~h}$. AcOEt was added to the mixture, and the solid was filtered; the filtrate was washed with $\mathrm{H}_{2} \mathrm{O}$, brine, dried, and concentrated in vacuo to give a residue that was purified by FC (PE/AcOEt $9.5: 0.5)$ to give $\mathbf{1 5}(0.52 \mathrm{~g}, 68 \%)$. White solid. M.p. $106-107^{\circ}$ $(\mathrm{MeOH}) .{ }^{1} \mathrm{H}-\mathrm{NMR}\left(\mathrm{CDCl}_{3}\right)$ : $7.41-7.34(m, 4$ arom. $\mathrm{H}) ; 7.16-7.09(m, 4$ arom. $\mathrm{H}) ; 6.72(s, \mathrm{CH}$ (pyrazole)); $5.43\left(s, \mathrm{CH}_{2}\right) ; 2.37(s, \mathrm{Me}) .{ }^{13} \mathrm{C}-\mathrm{NMR}\left(\mathrm{CDCl}_{3}\right)$ : $144.9 ; 143.5\left(q,{ }^{2} J=38\right) ; 140.2 ; 139.4 ; 132.3$; $130.0 ; 129.7 ; 128.7 ; 126.1 ; 125.7 ; 121.2\left(q,{ }^{1} J=267\right) ; 105.8\left(q,{ }^{3} J=2\right) ; 73.8 ; 21.3$. EI-MS: $377\left(100, M^{+}\right), 331$ (85), 300 (90). Anal. calc. for $\mathrm{C}_{18} \mathrm{H}_{14} \mathrm{~F}_{3} \mathrm{~N}_{3} \mathrm{O}_{3}$ (377.32): C 57.30, H 3.74, N 11.14; found: C 57.30, H 3.91, N 10.82 .

Evaluation of Stability in Human Serum and in Whole Human Blood. Blood samples for both stability, COX selectivity, and platelet aggregation assays were obtained from healthy volunteers who had not taken any drug for at least two weeks. Volunteers, who were treated according to the Helsinki protocol for biomedical experimentation, gave their informed consent to the use of blood samples for research purposes.

Compounds 7, 11, and 15 were incubated in human serum (sterile-filtered from human male AB plasma, Sigma-Aldrich) and in heparinized human blood at $100 \mu \mathrm{m}$ concentration. The resulting solns. were maintained at $37 \pm 0.5^{\circ}$, and, at appropriate time intervals, the mixtures were diluted $1: 2$ with MeCN containing $0.1 \% \mathrm{CF}_{3} \mathrm{COOH}$ in order to deproteinize and precipitate cells, proteins, and enzymes. Samples were sonicated, vortexed, and then centrifuged for $15 \mathrm{~min}$ at $2150 \mathrm{~g}$. The clear supernatant was filtered by $0.45 \mu \mathrm{m}$ PTFE filters (Alltech) and analyzed by RP-HPLC.

The RP-HPLC procedure allowed separation and quantitation of remaining compounds and metabolites. HPLC Analyses were performed with an HP1100 chromatograph system (Agilent Technologies, Palo Alto, CA, USA) equipped with a quaternary pump (model G1311A), a membrane degasser (model G1379A), a diode-array detector (DAD; model G1315B) integrated in the HP1100 system. Data were analyzed using an HP ChemStation system (Agilent Technologies). The anal. column was a ZORBAX Eclipse XDB-C8 $(4.6 \times 150 \mathrm{~mm}, 5 \mu \mathrm{m}$; Agilent $)$. The mobile phase consisted of MeCN/ $\mathrm{H}_{2} \mathrm{O}(70: 30)$ with $0.1 \% \mathrm{CF}_{3} \mathrm{COOH}$, and the flow-rate was $1.2 \mathrm{ml} / \mathrm{min}$. The injection volume was $20 \mu \mathrm{l}$ (Rheodyne, Cotati, CA). The column effluent was monitored at 226 and $254 \mathrm{~nm}$. Quantitation was achieved by comparison of peak areas with standards chromatographed under the same conditions.

Cyclooxygenase Inhibition Studies. A whole blood assay [15] was performed to evaluate the ability of synthesised compounds to inhibit COX-1 and COX-2.

Blood samples were divided in two aliquots to test COX-1 and COX-2 inhibition. The COX-2 aliquots were treated with $10 \mathrm{IU} / \mathrm{ml}$ of sodium heparine, $10 \mu \mathrm{g} / \mathrm{ml}$ acetylsalicylic acid, and $10 \mu \mathrm{g} / \mathrm{ml}$ 
lipopolysaccaride (LPS) from E. coli. Methanolic solns. of the tested compounds at different concentrations were prepared, $10-\mu \mathrm{l}$ aliquots were distributed in incubation tubes, and the solvent was evaporated. The residues were dissolved by vortexing either in $1 \mathrm{ml}$ of heparinized blood to test COX-2 inhibition, or in $1 \mathrm{ml}$ of untreated blood to test COX-1 inhibition. The final concentrations of the tested compounds were, therefore, diluted 100 times in the incubation tubes. The COX-1 aliquots were incubated in glass tubes for $1 \mathrm{~h}$ at $37^{\circ}$, which is sufficient to complete coagulation, then centrifuged at $2000 \mathrm{~g}$ for $10 \mathrm{~min}$, after which the serum was ready to be tested for platelet $\mathrm{TxB}_{2}$ production. \% Inhibition in samples treated with the test compounds was evaluated in comparison with control samples with basal $\mathrm{TxB}_{2}$ production.

The COX-2 aliquots were incubated in polyethylene tubes for $24 \mathrm{~h}$ at $37^{\circ}$ to allow $\mathrm{COX}-2$ expression in monocytes and maximal $\mathrm{PGE}_{2}$ production. They were then centrifuged at $2000 \mathrm{~g}$ for $10 \mathrm{~min}$ after which the plasma was ready to be tested for $\mathrm{PGE}_{2}$ production. Basal $\mathrm{PGE}_{2}$ production in blood untreated with LPS was subtracted from values for each sample, and \% inhibition in samples incubated with tested compounds was calculated $v$ s. control samples with maximal $\mathrm{PGE}_{2}$ production.

Prostanoid production was evaluated by enzyme immunoassay, following the specific instructions provided by Cayman Chemical, based on a competitive reaction, for COX-1, between $\mathrm{TxB}_{2}$ and a $\mathrm{TxB}_{2}$ acetylcholinesterase conjugate $\left(\mathrm{TxB}_{2}\right.$ tracer) for a specific $\mathrm{TxB}_{2}$ antiserum, and, for $\mathrm{COX}-2$, between $\mathrm{PGE}_{2}$ and $\mathrm{PGE}_{2}$-acetylcholinesterase $\left(\mathrm{PGE}_{2}\right.$-tracer) for a specific $\mathrm{PGE}_{2}$ antiserum. Standard curves with known concentrations of $\mathrm{TxB}_{2}$ and of $\mathrm{PGE}_{2}$ were used to determine prostanoid concentrations in the sample wells. \% Inhibition in compound-treated samples was calculated by comparison with untreated controls. The concentration of the tested compounds causing $50 \%$ inhibition $\left(I C_{50}\right)$ was calculated from the concentration-inhibition response curve (5-6 experiments).

Inhibition of Platelet Aggregation in vitro. Platelet rich plasma (PRP) was prepared by centrifugation of citrated blood at $200 \mathrm{~g}$ for $20 \mathrm{~min}$. Aliquots $(500 \mu \mathrm{l})$ of PRP were added into aggregometer (Chrono$\log 4902 D)$ cuvettes, and aggregation was recorded as increased light transmission under continuous stirring $(1000 \mathrm{rpm})$ at $37^{\circ}$ for $10 \mathrm{~min}$ after addition of the stimulus. Collagen $(1.0 \mu \mathrm{g} / \mathrm{ml})$ was used as platelet activator in PRP. The inhibitory activity of the compounds was tested by addition of drug to PRP $10 \mathrm{~min}$ before addition of the stimulus (collagen). Drug vehicle ( $\leq 0.5 \%$ DMSO) added to PRP did not affect platelet function in control samples. At least, five experiments were performed for each compound. The potential role of NO and sGC in the inhibitory effect of $\mathbf{1 5}$ was verified using the sGC inhibitor, ODQ $(100 \mu \mathrm{M})$.

The anti-aggregatory activity of the test compounds was evaluated as \% inhibition of platelet aggregation compared to controls (5-6 experiments), and $I C_{50}$ values were calculated by nonlinear regression analysis.

Vasodilating Activity Assay. Thoracic aortas were isolated from male Wistar rats weighing 180-200 g. The endothelium was removed, and the vessels were helically cut: three strips were obtained from each aorta. The tissue was placed in organ baths containing $30 \mathrm{ml}$ of Krebs-bicarbonate buffer of the following composition (mM): $\mathrm{NaCl} 111.2, \mathrm{KCl} 5.0, \mathrm{CaCl}_{2} 2.5, \mathrm{MgSO}_{4} 1.2, \mathrm{KH}_{2} \mathrm{PO}_{4} 1.0, \mathrm{NaHCO}_{3}$ 12, glucose 11.1 maintained at $37^{\circ}$ and continuously gassed with $95 \% \mathrm{O}_{2} / 5 \% \mathrm{CO}_{2}(\mathrm{pH} 7.4)$. The aortic strips were allowed to equilibrate for $120 \mathrm{~min}$ and then contracted with $1 \mu \mathrm{M}(-)$-phenylephrine. When the response to the agonist reached a plateau, cumulative concentration-response curves to compounds 7, 11, and 15 were determined. The effect of $1 \mu \mathrm{M}$ ODQ was evaluated in a separate series of experiments in which the ODQ was added $5 \mathrm{~min}$ before contraction. $E C_{50}$ Values are means of 5-9 determinations. Responses were recorded by an isometric transducer connected to the MacLab System PowerLab ${ }^{\circledR}$.

\section{REFERENCES}

[1] A. L. Blobaum, L. J. Marnett, J. Med. Chem. 2007, 50, 1425.

[2] G. A. FitzGerald, C. Patrono, N. Engl. J. Med. 2001, 345, 433.

[3] L. Gasparini, E. Ongini, G. Wenk, J. Neurochem. 2004, 91, 521.

[4] Y. S. Bakhle, Br. J. Pharmacol. 2001, 134, 1137.

[5] E. M. Antman, D. DeMets, J. Loscalzo, Circulation 2005, 112, 759. 
[6] J.-M. Dogné, C. T. Supuran, D. Pratico, J. Med. Chem. 2005, 48, 2251.

[7] S. Moncada, E. A. Higgs, Br. J. Pharmacol. 2006, 147, S193.

[8] R. R. Ranatunge, M. Augustyniak, U. K. Bandarage, R. A. Earl, J. L. Ellis, D. S. Garvey, D. R. Janero, L. G. Letts, A. M. Martino, M. G. Murty, S. K. Richardson, J. D. Schroeder, M. J. Shumway, S. W. Tam, A. M. Trocha, D. V. Young, J. Med. Chem. 2004, 47, 2180.

[9] C. Velázquez, P. N. P. Rao, R. McDonald, E. E. Knaus, Bioorg. Med. Chem. 2005, 13, 2749.

[10] E. Del Grosso, D. Boschi, L. Lazzarato, C. Cena, A. Di Stilo, R. Fruttero, S. Moro, A. Gasco, Chem. Biodiversity 2005, 2, 886 .

[11] K. Chegaev, L. Lazzarato, P. Tosco, C. Cena, E. Marini, B. Rolando, P.-A. Carrupt, R. Fruttero, A. Gasco, J. Med. Chem. 2007, 50, 1449.

[12] T. D. Penning, J. J. Talley, S. R. Bertenshaw, J. S. Carter, P. W. Collins, S. Docter, M. J. Graneto, L. F. Lee, J. W. Malecha, J. M. Miyashiro, R. S. Rogers, D. J. Rogier, S. S. Yu, G. D. Anderson, E. G. Burton, J. N. Cogburn, S. A. Gregory, C. M. Koboldt, W. E. Perkins, K. Seibert, A. W. Veenhuizen, Y. Y. Zhang, P. C. Isakson, J. Med. Chem. 1997, 40, 1347.

[13] S. K. Singh, M. S. Reddy, S. Shivaramakrishna, D. Kavitha, R. Vasudev, J. M. Babu, A. Sivalakshmidevi, Y. K. Rao, Tetrahedron Lett. 2004, 45, 7679.

[14] B. Testa, J. M. Mayer, 'Hydrolysis in Drug and Prodrug Metabolism - Chemistry, Biochemistry, and Enzymology', Verlag Helvetica Chimica Acta, Zürich, Wiley-VCH, Weinheim, 2003, p. 534.

[15] P. Patrignani, M. R. Panara, A. Greco, O. Fusco, C. Natoli, S. Iacobelli, F. Cipollone, A. Ganci, C. Créminon, J. Maclouf, J. Pharmacol. Exp. Ther. 1994, 271, 1705.

[16] J. J. Talley, Prog. Med. Chem. 1999, 36, 201.

[17] A.-A. Weber, T. Neuhaus, C. Seul, R. Düsing, K. Schrör, A. Sachinidis, H. Vetter, Eur. J. Pharmacol. 1996, 309, 209.

[18] S. Ganapathy, B. B. V. Soma Sekhar, S. M. Cairns, K. Akutagawa, W. G. Bentrude, J. Am. Chem. Soc. 1999, 121, 2085.

[19] R. Soliman, J. Med. Chem. 1979, 22, 321

[20] R. B. Kelly, E. G. Daniels, J. W. Hinman, J. Org. Chem. 1962, $27,3229$.

Received October 10, 2008 